\title{
Atatürk'ün kırsal kalkınma projesi "İdeal Cumhuriyet Köyü Projesi" nin mekân kuramları açısından değerlendirilmesi
}

\section{Evaluated of "Ideal Republic Village" rural development project of Atatürk from the point of space theories}

\author{
Ömer ATABEYOĞLU
}

Ordu Üniversitesi, Ziraat Fakültesi, Peyzaj Mimarlığı Bölümü, Ordu, Türkiye

\author{
Eser Bilgisi / Article Info \\ Araştırma makalesi / Research article \\ DOI: $10.17474 /$ artvinofd.297142 \\ Sorumlu yazar / Corresponding author \\ Ömer ATABEYOĞLU \\ e-mail: atabey6@hotmail.com \\ ORCID: 0000000172308598 \\ Geliş tarihi / Received \\ 10.03.2017 \\ Düzeltme tarihi / Received in revised form \\ 11.09.2017 \\ Elektronik erişim / Online available \\ 25.09.2017 \\ Anahtar kelimeler: \\ Algı \\ Mekân \\ Lynch Gestalt \\ Norberg-Schulz \\ Kırsal kalkınma
}

Keywords:

Perception

Lynch

Gestault

Norberg-Schulz

Rural development

\begin{abstract}
Özet
Köyler, ülke kalkınmasının temelini oluştururlar. Gelişmiş ülkeler için köylerin geliştirilmesi bir devlet politikasıdır. Türkiye'de de köyler ile ilgili önemli adımlar atılmıştır. Bu adımların en önemlilerinden birisi Cumhuriyetin ilk yıllarında hazırlanan köy projesidir. Çalışmanın materyalini, İdeal Cumhuriyet Köyü projesi oluşturmaktadır. 1937 Yılında çizdirilen proje Atatürk'ün de büyük önem gösterdiği, katkıda bulunduğu ve özel olarak ilgilendiği önemli bir projedir. Model, hem köylerdeki kültürel ve sosyal yapıyı desteklediği, hem de üretim ve refahı artırdığından ilham verici özelliklere sahiptir. Bu ve benzeri modeller kentlerin ve köylerinin gelişimi açısından önemlidir. Çalışma, projenin Lynch, Norberg-Schulz ve Gestalt'un mekân ve tasarım kuramları açısından değerlendirilmesini kapsamaktadır. Bu yolla projenin mekân örgüsü ve tasarımı objektif olarak değerlendirilmiştir.
\end{abstract}

\begin{abstract}
The villages are the base of the country's development. It is a national policy the villages are developed for the developed countries. There are the important steps about the villages in Turkiye. The important one of the steps is a village project prepared in first years of The Republic. Material of the study is the project of Ideal Republic Village. The project was drawn in 1937. Atatürk was interested and contributed to the project. The project has inspirational characteristics, as model both supports cultural and social structure and increases production and welfare in the villages. This and similar projects are important for development of urban and villages. The study contains analyzing of the project with space and design theories of Lynch, Norberg-Schulz and Gestault. With this way, space structure and design of the project were evaluated objectively.
\end{abstract}

\section{Giriş}

Kurtuluş savaşından yeni çıkmış olan Türkiye, Cumhuriyetin ilanı ile hızlı bir gelişim ve değişim sürecine girmiştir. Bu süreç içerisinde gerçekleştirilen pek çok önemli değişim ve kaydedilen önemli ilerlemeler ülkenin hızlı bir şekilde toparlanmasının da önünü açmıştır. Savaştan yeni çıkmış ve hırpalanmış ülke kaynaklarının yeniden verimli kullanılır hale getirilmesi, tahrip olmuş kentler ve köylerin imar edilmesi, ticaretin geliştirilip ekonominin desteklenmesi ve eğitimin topyekûn artırıması pek çok fedakârlığı gerekli kılmıştır. Cumhuriyetin kurulmasından sonraki dönemde hem Atatürk, hem de Cumhuriyet ve Ülke için fedakârca çalışan herkes ilerleme ve büyümenin temellerini atacak projeler geliştirmişlerdir.
Köyler üretimin ön planda olduğu ve milli kalkınmanın önemli bir parçasıdır. Bu kapsamda köylerin önemli sorumlulukları mevcuttur. Ülkesel kalkınma da sorumlukların yerine getirilmesi ve üretim faaliyetlerinin devamlılı̆ı ile kaynakların doğru kullanılması ile gerçekleşir (Kaypak 2014). Kaynakların doğru ve verimli kullanılması ile üretimin artırılmasına en büyük katkı köylerden sağlanır. "Köylü Milletin Efendisidir" sözü de Atatürk'ün köy ve köylüye verdiği değeri göstermesi açısından önemlidir. Bu bakış açısıyla 18 Mart 1924 yılında 442 sayılı Köy Kanunu çıkartılmıştır. Köy Kanunu köy ile ilgili görevler, görev tanımları, yasal yönetsel işleyiş, köylünün yapacağı işler gibi pek çok konuda hükümler barındırmaktadır. Bunlara ilaveten aynı kanun köy imarı ve köyde yer alması gereken fonksiyonlar ile ilgili de kararlara sahiptir. Böylece köylerin yapısal gelişimi ile ilgili 
önemli adımlardan birisidir. 24 Nisan 1930 tarih ve 1593 sayılı Umumi Hıfzıssıhha Kanunu da köyler ilgili önemli düzenlemeler getirmiş, imarından ziyade köylerde sağlık ve hijyen konularına eğilmiş bir diğer önemli kanundur. 3 Nisan 1930 tarih ve 1580 sayılı Belediye Kanunu ise özellikle belediyecilik ve belediye sınırları içerisindeki alanlarla ilgili işleyişi düzenleyen kararlara sahip olup, köyler ile ilgili mekânsal kullanımdan ziyade, bazı yönetimsel konulara yer vermiş döneme ait bir diğer kanundur (Mevzuat 2016, URL 2016, İnce 2012, Kapluhan 2012, Sarı 2014).

Türkiye'de artan sanayileşme, 1950'li yıllarda köyden kente göçü tetiklemiştir (Güreşçi 2010). Bu durum köylerdeki üretimi zayıflatmıştır. Tam da bu noktada köy odaklı gerçekleştirilen proje ve çalışmaların amacı köyü eğitim, kültür ve sanayinin temeli haline dönüştürmek, köylünün eğitimli, sosyal, kültürlü, üretken, tarım ve hayvancılıkta modern yöntemleri kullanan kişiler olmasını sağlamaktır. Aynı zamanda, gelir ve refahı artırarak kırsal ve kentsel kesim arasındaki farklılıkları kaldırmak ve kırsal yerleşimlerin daha yaşanabilir hale dönüştürülmesi bir diğer amaçtır (Doğanay 1993, Çolakoğlu 2007). Köyler, korunarak toplumun temeli haline getirilmesi gereken milli kültür, adet ve geleneklerin tam anlamıyla yaşandığı ve korunduğu yerleşimlerdir (Dicle 2012).

1937 Yılında Atatürk'ün büyük katkıları ve uzmanlarca ortaya koyulan İdeal Cumhuriyet Köyü Projesi zamanın önemli bir köy projesidir. Atatürk, projenin uygulanmasını desteklemiş, ancak erken vefatı ile birlikte proje de yaygınlaşamadan kalmıştır. Proje içerisinde pek çok fonksiyon, detay ve özellik barındırmaktadır. Proje, üzerinde durulması ve değerlendirilmesi gereken kurgusal özelliklere sahiptir. Bu sistem içerisinde yer verilen ünite ve fonksiyonlar mekân kurgusu ve algısının şekillenmesinin önemli parçalardır.

Mekânların kurgulanması veya mevcut mekânların kurgusal açıdan değerlendirilmesinde çeşitli kuramlar yol göstericidir. Mekân kurgusu ve algısı ile ilgili pek çok kuram ortaya atılmış olmakla birlikte en önemlileri; Lynch, Norberg-schulz ve Gestalt kuramlarıdır (Özen 2006).

Bu çalışmanın da amacı; Türkiye'de köyler için geliştirilerek, projelendirilmiş ve uygulama aşamasına ulaşmış ilk çalışma olan; Atatürk'ün de önemle üzerinde durduğu ve bizzat geliştirilmesine katkı sağladığı "İdeal Cumhuriyet Köyü" projesinin mekân kurguları ve kuramları açısından değerlendirilmesidir. Böylece projenin mekânsal kurgusunun uygunluğu ve yeterliliğinin değerlendirilmesi amaçlanmıştır.

\section{MATERYAL ve YÖNTEM}

Çalışmanın materyalini 1937 yılında çizilen, Trakya Umumi Müfettişi General Kazım Dirik tarafından Atatürk'ün manevi kızı Afet İnan'a verilen ve üzerinde mimarının ismi bulunmayan "Ideal Cumhuriyet Köyü Projesi" oluşturmaktadır (Şekil 1). Atatürk projeyle bizzat ilgilenmiş, üzerinde çalışmış ve uygulanmasını desteklemiştir. Afet İnan, projenin aslını Türk Tarih Kurumu'na bağışlamış, köy projesine de kendi kitapları olan; "Cumhuriyetin 50. Yılı İçin Köylerimiz" ve "Devletçilik Illkesi ve Türkiye Cumhuriyetinin Birinci Sanayi Planı 1933"te değinmiştir. Çalışmanın yöntemini; Köy Projesinin alan kullanımları ve yerleşim planı açısından incelenmesi ile Norberg-Schulz ve Lynch'in Mekân Algıs ve Gestalt Kuramı açısından değerlendirilmesi oluşturmaktadır. Bu kapsamda önce proje ile ilgili veriler toplanmış, özellikle çalışma fikrini oluşturan Afet İnan'a ait "Cumhuriyetin 50. Yılı İçin Köylerimiz" ve "Devletçilik Illkesi ve Türkiye Cumhuriyetinin Birinci Sanayi Planı 1933" isimli kitaplar değerlendirilmiştir. Daha sonra, projenin mekansal ve kurgusal değerlendirmesinin somut temellere oluşturulması için Norberg-Schulz ve Lynch'in Mekan Algısı ve Gestalt Kuramı seçilmiştir. Seçilen mekân kuramları doğrultusunda köy planı; "yol", "yüzey", "bölge", "düğüm noktası" ve "yeryüzü işaretleri", "merkez veya yer", "yön ve yol", "alan veya sınır", "şekil-zemin ilişkisi", "yakınlık", "tamamlama", "benzerlik" ve "süreklilik" ilkelerine göre tanımlanabilecek detaylarına ayrılarak her bir ilke kapsamındaki çizimleri oluşturulmuştur. Bu sayede görseller üzerinden projenin incelenmesi ve yorumlanabilmesi sağlanmıştır.

Kent plancısı olan Lynch (1918-1984) kentsel çevrelerin algısal formları hakkındaki çalışmaları ile tanınır. Lynch mekân algısını (1960) "yol", "yüzey", "bölge", "düğüm noktası" ve "yeryüzü işaretleri" bazında değerlendirir. Buna göre "yol"; kullanıcıların alıştığı ve potansiyel olarak 
değerlendirilen kanallar; "yüzey", iki farklı bölüm arasında hat oluşturan, tek düzeliği kıran sahil, demiryolu, duvar gibi hatlar olup, kullanıcılar tarafından yol olarak değerlendirilmezler. "Bölge", aynı ve kendine has özellikler gösteren alanlar; düğüm noktası, yolların kesişim veya birleşim noktaları; "Kent simgesi veya yeryüzü işareti" ise, alan içerisindeki genel karakterden farlııklar ve değişimlerdir. İşaretler, kolayca ayırt edilebilir ve göze çarparlar.

Norberg-Shulz'a göre mekân algısı (1972) "merkez", "yön" ve "alan" kurgusunda gerçekleşir. "Merkez veya yer"; merkez bir çevredeki referans noktasıdır. Bütün merkezler eylemlerin yeridir. Buna göre merkezleri eylemin birim mekânı olarak tanımlamak mümkündür. "Yön ve yol"; her mekân içerisinde olan bir kavramdır. Yön kişinin çevre içerisindeki hareketini tanımlar. Kişinin mekân içerisindeki pozisyonunu belirlemesi bulunduğu noktadan ayrılması ile başlar ve seyahati boyunca yol kişinin amacı doğrultusunda ilerlemesine yardımcı olur. Algısal ve şematik olarak bir yolun karakteristik özelliği sürekliliğidir. "Alan veya sınır"; alan içerisinde yolların tanımlandığı, strüktüre edilmemiş "zemin" olarak tanımlanabilir".

Gestalt Kuramı (20.yy) "şekil-zemin iliş̧kisi", "yakınlık", "tamamlama", "benzerlik" ve "süreklilik" ilkelerini benimser. Şekil-zemin ilişkisinde "algıda seçicilik" kuramına göre, dikkatin yoğunlaştığı obje şekil, diğer yüzeyler zemindir. "Şekil ve zemin" mutlak kavramlar değildir, dikkatin yoğunlaştığı noktaya göre şekil ve zemin değişir. "Yakınlık ilkesi"; duyusal anlamda birbirlerine yakın olan uyarıcılar bir küme olarak algılanır. Buradaki yakınlık daha çok zaman ve mekân anlamındadır. "Tamamlama ilkesi"; duyusal anlamda eksik girdi içeren uyarıcılar tam olarak algılanır. "Benzerlik ilkesi"; bazı duyusal özellikler benzer olan cisimler bir küme olarak algılanır. "Süreklilik ilkesi"; belirli bir yönde ilerleyen uyarıcılar bir bütün olarak algılanır. Projenin kuramlar açısından değerlendirilmesi sürecinde Lynch ve Norbergshulz'un bir birini karşılayan ilkeleri birlikte değerlendirilmiş, Gestalt kuramı ise farklılığı nedeniyle diğer ikisinden ayrı olarak incelenmiştir.

\section{İdeal Cumhuriyet Köyü Projesi}

Proje dairesel düzende ve ışınsal akslarla kurgulanmıştır. Üç tane birincil, bir tane ikincil statüde dairesel yol planı projenin ana hatlarını oluşturmaktadır. Bu dairesel düzen içten dışa doğru merkezde köy meydanı ve kurumsal yapılar, çevreleyen dairede yaşam alanları ve sonrasında da kırsal alan kullanımlarını barındırmaktadır. Plan 138 haneli olarak kurgulanmıştır. Köyde 43 adet kuruma yer verilmiş olup, bu kurumlar bir köyde ihtiyaç duyulabilecek, eğitim, sosyal ve kültürel yaşam, üretim, depolama, satış ve yönetime dair unsurları barındırmaktadır. Beş adet ışınsal yol alanı baştanbaşa kat etmektedir. Bu yollar hem çevre köyler ile hem de köy katmanlarının kendi içlerindeki bağlantılarını kurmaktadır. Yerleşimin merkezinde bir meydan oluşturulmuştur. Yollar merkezde, köy meydanına bağlanmaktadır. Köy projesinde pek çok farklı fonksiyona yer verilmiştir (Şekil 1).

Kategorilere göre projede yer alan unsurlar;

- Kültürel mekânlar; Konferans salonu, ziraat ve el işleri müzesi

- Sosyal mekânlar; Sosyal kurumlar, halk odası, gençler kulübü, köy gazinosu

- Ticarethaneler; Kooperatifler, köy dükkânları, pazar yeri ve köy zahire loncası, berber, terzi, nalbant, marangoz, kalaycı, demirci, firıncı, arabacı

- Konaklama; Konuk odası, han, köy konağı, otel

- Dini mekânlar; Cami, asri mezarlık

- Üretim; Mandıra, fabrika, değirmenler, kanara, kireç, taş, tuğla ve kiremit ocakları

- Su ile ilişkili elemanlar; Çeşmeler, hamam, artezyen, yunak yeri, umumi tuvalet, su deposu

- Teknik yapılar; Telefon santrali, köy söndürgesi

- Sağlık; Ebe, Sağlık korucusu, revir, etüv makinesi, veteriner

- Rekreasyon; Çocuk bahçesi, köy parkı, panayır yeri, spor sahası

- Eğitim alanları; Okul ve uygulama bahçesi, okuma odası, öğretmen evi

- Hayvancılık; Hayvan sağlığı korucusu, Fenni ağıl, aşım durağı, tavuk, tavşan, arı istasyonları, damızlık ahır, hayvan mezarlığı

- Tarım; Yonca ve hayvan pancar tarlası, koruluk, gübrelik, tarımbaşı, fidanlık, selektör binası 


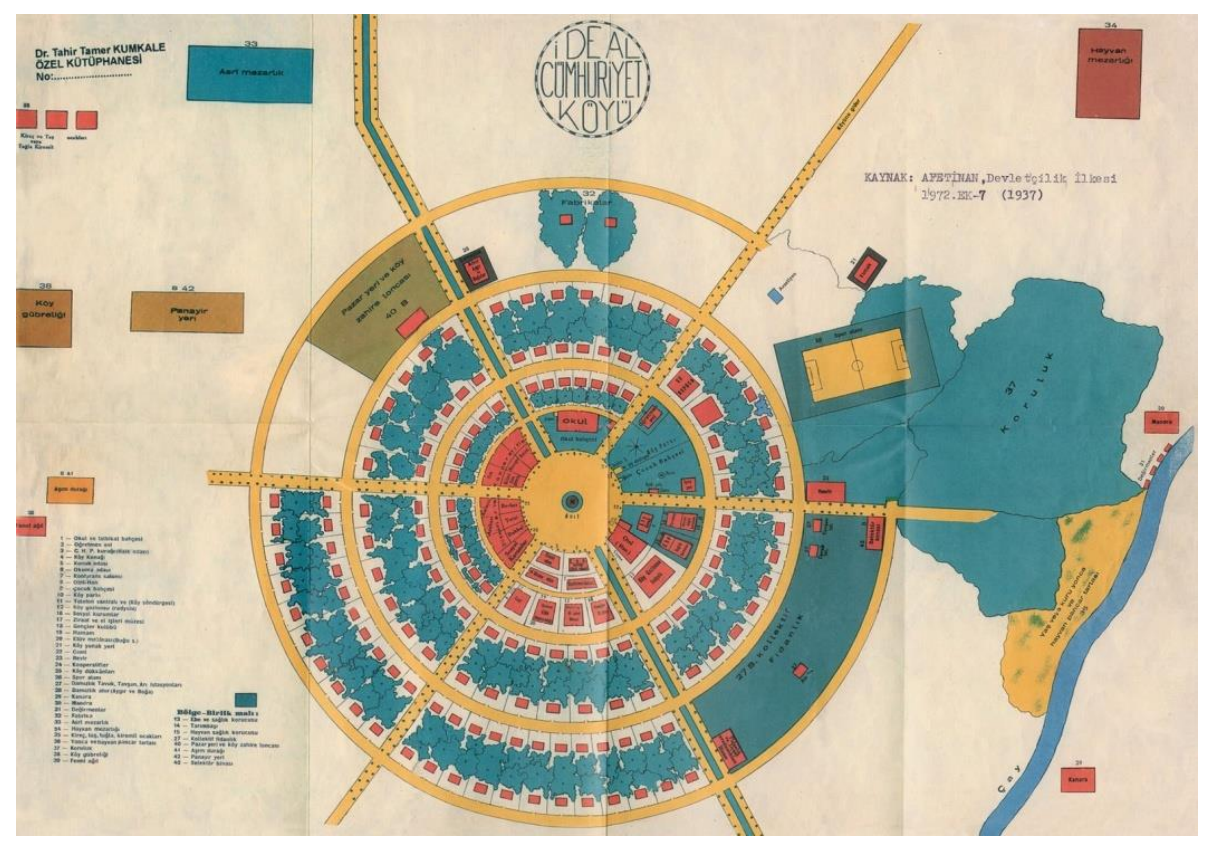

Şekil 1. İdeal Cumhuriyet Köyü Projesi (İnan 1972)

Konaklama ihtiyaçlarını karşılamak ve köyü turistik anlamda da destekleyecek olan bir otel ve bir konuk odası meydanın yakınına konumlandırıımışır. Köy dâhilinde üretim faaliyetlerinin de gerçekleştirilebilmesine olanak sağlayacak olan mandıra, fabrika, değirmenler, kanara, kireç, taş, tuğla ve kiremit ocakları kurgulanmıştır. Bu durum, köyün kendi ihtiyaçlarını karşılaması, ürettim sağlaması, imar faaliyetlerini desteklemesi ve yerel inşaat özellikleri ve malzemelerinin kullanılıp, korunmasını sağlayacak önemli bir etkendir. Projede su ile ilgi olarak da pek çok unsura yer verilmiştir. Bunlar gerek köyün temizlik ve içme su ihtiyacının karşılanması, gerekse tarım ve hayvancılık için kullanılmasında önemlidir. Özellikle çeşmeler okul bahçesi, park gibi kullanımın yoğun bulunduğu yerlere konumlandırılmıştır.

Köyde sağlık ihtiyaçlarının karşılanması için de imkânlar düşünülmüştür. Bunlar ulaşılabilirlik açısından meydan ve aks çevresine konumlandırılmış, böylece köy sakinlerinin kolay ulaşımı mümkün kılınmıştır. Köyler, doğal kaynaklar açısından son derece zengin yerleşimler olmasına rağmen yerleşim alanı içerisinde de rekreasyon alanlarına yer verilmiştir. Bu, yerleşim içerisinde de yeşil alan zenginliği artırmakta ve korumakta, ayrıca köy sakinleri için de rekreasyonel imkânlar sunmaktadır.

Köylünün her ihtiyacı için kasaba veya şehre gitme zorunluluğunu azaltan, köyün kendi kendine yetebilmesine etken olan ticarethaneler de proje de yer verilmiş olan diğer fonksiyonlardır. Ticarethaneler de hareketliliğin yoğun yaşandığı ve herkese ulaşılabilir olan köy meydanının çevresinde konumlandııımışlardır. Sadece pazar yeri, hem daha büyük hem de geçici bir etkinlik olması sebebiyle köy periferisinde yer almaktadır.

Yerleşkede eğitim alanları da düşünülmüş olup, meydanın hemen çevresinde bulunmaktadır. Bu eğitim alanları hem örgün eğitimi, hem de yaygın eğitimi destekleyen, okuma alışkanlığı kazandıran unsurlar barındırmaktadır. Okul yerleşkesindeki uygulama bahçesi ise eğitimin niteliğini artıracak önemli bir özelliktir. Kültürel mekânlar köyün önemli artılarından olup, meydandan sonraki iki halkanın üzerine nispeten daha sakin ancak ulaşılabilir bir konuma yerleştirilmişlerdir. Köydeki kültürel mekânlar, hem kültürel gelişime katkı sağlayacak, hem de müzeler vasıtasıyla turizme katkı sağlayacak etkenlerdir. Ayrıca, yerleşimdeki müzeler ile yöresel gelenek, adet ve kültürün yaşatılması ve korunması da mümkündür.

Hayvancılık ile ilgili fonksiyonlar yerleşimin dışında olacak şekilde kurgulanmıştır. Bu, fonksiyonlardan kaynaklanan rahatsı edici ve hastalıklara sebebiyet verebilecek etkenlerin köyü etkilemesinin önüne geçecek bir önlemdir. Ayrıca, köyde ölen hayvanların gelişigüzel gömülmesin ve sağlık tehdidi oluşturmasını engellemek üzere yerleşimin çok dışında, uzak bir yere 
konumlandırılan hayvan mezarlığı diğer bir detaydır. Köyün temel işlevi olan tarımsal faaliyetler için de pek çok fonksiyon yerleşimde planlanmıştır. Kolay ulaşılabilir mesafelerde, özellikle rahatsı edici etkenlere sahip olmayan fonksiyonlar yerleşimin dış çemberinde, köy üzerine etkisi olabilecek fonksiyonlar niteliğine göre daha uzakta konumlandırılmıştır. Bu fonksiyonlar, köylünün üretim alanlarını, üretimde kullanacağı materyalleri, ham maddeleri, işleme ve saklama alanlarını içerir.

Köyün iletişim ve yangın güvenliğinin sağlanması amacıyla teknik fonksiyonlarda unutulmamıştır. Böylece, kent hem sosyal ve ticari anlamda iletişimini sağlayabilecek, hem de yangın tehlikesine karşı önlemini almış olmaktadır. Sosyal mekânlar, bir yerleşimin önemli parçalarından birisidir. Bu maksatla yerleşim genelinde, özelikle de köy meydanı çevresinde sosyal imkânlar tesis edilmiştir. Dini gerekler de köy içerisinde düşünülmüş, köy evlerinin bulunduğu parselde ve herkesin kolayca ulaşabileceği merkezi bir konumda cami planlanmıştır. Ayrıca, yerleşimin dışında, ancak köyden de geçen ana yolun hemen üzerinde asri mezarlığa yer verilmiştir.

Yerleşim genelinde yoğun bir yeşil doku oluşmasına gayret edilmiştir. Köy evlerinin tamamı bahçeli olarak ve haneleri plantasyonla ayıran bir tasarım düzeni kurgulanmıştır. Ayrıca yerleşimin hemen çevresinde de geniş koruluklar ve fidanlıklar tesis edilmiştir. Böylece yerleşimin kırsal dokuyla uyumlu gelişmesi, çevresel ve doğal karakterin korunması, doğal imajın yerleşim içerisinde de değerlendirilmesi sağlanmıştır.

\section{BULGULAR}

İster iç, ister dış mekân olsun, tasarım için fonksiyonel ve estetik gerekler sağlandığı sürece alternatifler sınırsızdır. Durum böyle olunca mekân tasarımında doğruya ulaşmanın pek çok farklı yol bulunduğundan bahsedilebilir. Bir mekânın değerlendirilebilmesine intiyacı karşılama, güvenlik, estetik olma, çözüm sağlama, ergonomi gibi genel kabuller ve evrensel doğruların dışında, kullanışlılığı tecrübe edilmiş kuram ve teoriler kolaylık sağlamaktadır. Lynch, Norberg-Shulz ve Gestalt çeşitli kriterler bakımından mekân incelemesini mümkün kılan kuramlardır.
Lynch Ve Norberg-Shulz'un Mekân Kuramları Açısından Inceleme

Çalışma da; bu iki kuram bir birine benzer değerlendirme elemanları ve bir birini destekler özellikleri nedeniyle birlikte değerlendirilmişlerdir. Bu kuramlar mekânı; "yol", "yüzey", "bölge", "düğüm noktası" ve "yeryüzü işaretleri", "merkez veya yer", "yön ve yol", "alan veya sınır" açısından değerlendirmektedir.

\section{Yol ve yön}

İnsanların gezinmek için kullandıkları rotalar, kaldırımlar, sokaklar ve tüm diğer kanallardır. Yerleşim yeri sakinlerinin, yerleşim yerindeki hareketleri için değerlendirdikleri tüm sirkülasyon öğeleri bu kentsel öğeyi teşkil eder. Yollar kendi içerisinde bir hiyerarşiye sahiptir. Yolların nitelikleri ve aralarındaki hiyerarşi kent içerisinde mekânların tanımlanmasında etkilidir. Yollar mekânlar için önemli ayırt edici öğelerdir.

Projede merkezden ışınsal olarak dağılan yollar ile bu yolları kesen dairesel yollar yerleşimin mekân algısını oluşturan önemli bir parçasıdır. Hiyerarşik olarak yollar arasında bir farklılık ve düzen mevcuttur. Bu hiyerarşik düzen yerleşimdeki mekânlar arasında farklııılar ortaya koymakta, önem derecesi yüksek olan yolun üzerindeki fonksiyonların bununla ilişkilendirilmesini sağlamaktadır. Düz ve ışınsal yollar mekânın derinlemesine görülmesini ve böylece algılanması kolaylaştırmaktadır. Dairesel yollar ise sürprizli mekânlar ortaya koymakta, algıyı zayıflatıp merak duygusunu artırıcı etki oluşturmaktadır. Çevre yerleşimler ile bağlantısını sağlayan yolun nitelik açısından diğer yollardan farklılık göstermek üzere refüjlü tasarlanmış olması yerleşim özelliklerinin doğru okunmasını kolaylaştırmaktadır.

\section{Yüzey, kenar ve sınır}

Kıyı kenar çizgisi, bina veya duvar gibi algısal sınırlardır. Mekânı sınırlandıran, geçişi ve ulaşımı engelleyen, sirkülasyonu zorunlu olarak yönlendiren zaman zaman görüntüyü perdeleyen, bariyer niteliğindeki kent öğeleridir. Kent içerisinde bu nitelikteki oluşumlar doğal veya insan yapımı elemanlardır.

Projede dairesel düzen çevresinde sıralan yapı kitleleri mekânların sınırlarını oluşturmaktadır. Yapı yüzeyleri ve duvarlar algısal sınırlar ve zorunlu yönlendirmeler 
sağlamaktadır. Kırsal alan kullanımı nedeniyle yapılar düşük kat sayısı ve irtifaya sahip olacaktır. Bu durum, yapıların sınır oluşturmasına rağmen algısal açıdan kullanıcılar üzerine baskı oluşturmasını engelleyecektir. Bununla birlikte yapıların dışında projede yer alan üniteler de sınırlandırıcı etkiye oluşturarak alanların niteliklerine göre kullanılmasını sağlamakta, amacı dışında veya bilinçsizce kullanılmasını engellemektedir. Bu fonksiyon sınırları projeye göre yeri geldiğinde çit veya duvar, yeri geldiğinde bordür, yeri geldiğinde ise nitelik değişimi ile gerçekleşmektedir. $\mathrm{Bu}$ kapsamda fonksiyonlar niteliklerine göre algısal ve fiziksel olarak sınırlandırılmıştır.

\section{Bölge ve alan}

Belirleyici özellik ve karaktere sahip geniş parçalardır. Kent, pek çok farklı alanın bir kompozisyonudur. Kentsel alanlar farklı nitelikteki fonksiyonlardır. Niteliksel değişimler ve özel karakterler mekânın bütünden ayrışmasını sağlayarak algılamayı ve tanımayı kolaylaştırır. Kentsel alan içerisinde benzer özelliğe sahip kent parçaları kentsel bölgeleri oluşturur.

Projede farklı fonksiyon ve niteliklere sahip pek çok alana yer verilmiştir. Meydan ve ortak kullanım, konut, rekreasyon, üretim ve pazarlama alanları gibi nitelik açısından, tasarımsal unsurlar ve algısal olarak ayrılmış belirgin alanlar mevcuttur. Alanlar arası ulaşım sirkülasyon öğeleri ile sağlanmış olup, alanlar barındırdıkları unsur, içerik ve hizmet amacıyla uyumlu oluşturulmuşlardır.

\section{Düğüm noktası ve merkez}

Kentteki kesişim ve odak noktasıdır. Yerleşim yeri genelinde sirkülasyonu sağlayan kanalların kesiştikleri yerler ile bu kesişimlerden ortaya çıkan meydanlar düğüm noktalarını oluşturur. Kesişen kanalların niteliği düğüm noktalarının da niteliğini belirler. Bu düğüm noktaları, her biri birbirinden farklılaşan özellikleri ve kentliyle olan etkileşimli fonksiyonları ile kentsel algılanabilirliği artırırlar.

Yerleşim, paralel ve ışınsal yolların bir birini kesmesi nedeniyle oldukça fazla düğüm noktasına sahiptir. Projedeki en önemli düğüm noktası, yerleşimin merkezinde yer alan meydandır. Meydan, ışınsal yollarının tamamının birleştiği hem bir kesişim, hem de geçiş noktasıdır. En önemli düğüm noktası aynı zamanda etkinlik, toplanma ve dağılma gibi fonksiyonları da üstlenen bir merkez konumundadır. Bunun dışında, farklı hiyerarşik düzeydeki ve nitelikteki yolların kesişiminden de pek çok düğüm noktası ortaya çıkan bir tasarım söz konusudur. Bu dügüm noktaları yönlendirmeyi ana işlev olarak üstlenmiş olup, farklı fonksiyonlara sahip değillerdir. Ana akstan fonksiyon bölgelerine geçiş için yönlendirme fonksiyonuna sahiptirler (Şekil 2).

\section{İşaret öğesi}

Tanımlanabilen referans noktalarıdır. Yerleşim yeri içerisinde anlam veya işlev olarak farklılaşan, dikkat çeken, tanıma veya tanımlama öğesi olarakön plana çıkan unsurlardır. Bu çağrışımı oluşturan yapay veya doğal elemanlar işaret öğesi olarak değerlendirilebilir.

Yerleşim planında işaret öğesi olarak ortaya çıkan baskın ve fazla unsur bulunmamaktadır. Bu kapsamda değerlendirilebilecek unsurlardan birisi yerleşimin meydanında yer alan heykeldir. Hem meydanı tanımlayıcı bir unsur, hem de sanatsal bir öğe olarak ortaya çıkmaktadır. Ayrıca yerleşimin kıyısına konumlandırılan değirmenler de yapısal öğeler olarak tanımlayıcı ve betimleyici işaret öğeleri olarak belirmektedir. Kırsal alan içerisinde dairesel ve merkezcil yerleşim formuyla yerleşimin kendisi de bir işaret öğesi teşkil etmektedir.

\section{Gestalt Kuramı'ı Açısından İnceleme}

Bu kuram mekânı; "şekil-zemin illişkisi", "yakınlık", "tamamlama", "benzerlik" ve "süreklilik" bakımından değerlendirmektedir. Çalışma kapsamında ele alınan projenin incelenmesi için de bu değerlendirme elemanları kullanılmıştır.

\section{Şekil-zemin iliş̧kisi}

Gestalt'a göre şekiller doğrudan veya dolaylı olarak algılanabilen şekilde yorumlar ortaya çıkartırlar ve bu durum şekil ve zeminin arasındaki ilişkinin bir ifadesidir. Buna göre; çevresinde doğrudan ilişkili olduğu veya bütünleyen tasarım unsurlarına göre tasarımın şeklini oluşturan olgu göründüğünden daha farklı ve derin algılara sahip olabilmektedir. Böylece de, ifade edilmek istenilen doğrudan ifade edilebileceği gibi, dolaylı yolla da algı oluşturulabilir. 


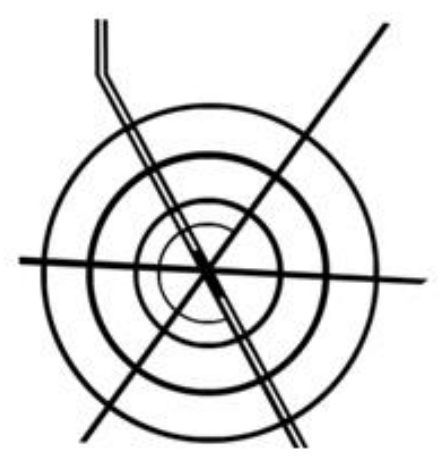

Yol, yön

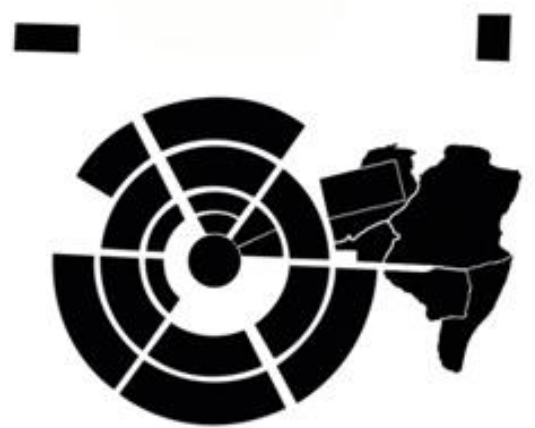

Bölge, alan

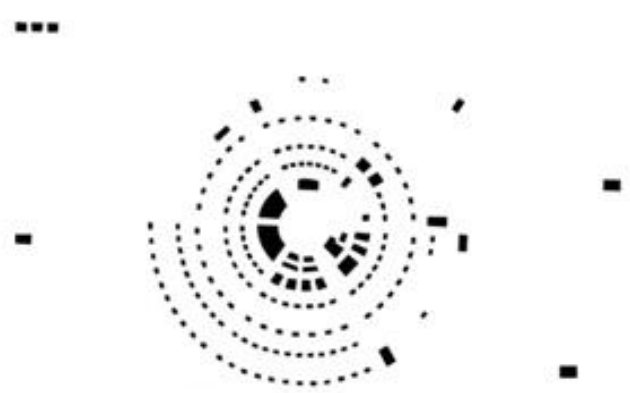

Yüzey, sınır

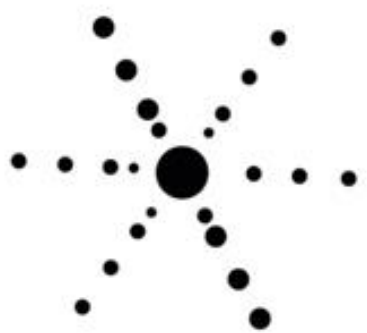

Düğüm noktas1, merkez

Şekil 2. Lynch ve Norberg-Shulz'un alan kuram öğelerine göre İdeal Cumhuriyet Köyü Projesinin parçaları

Şekil itibariyle planın ana formunu oluşturan daire, doğa ile en uyumlu formlardan birisidir. Dairesel yollar ve ışınsal akslar bir birlerini tamamlayarak yerleşim sakinlerince kolay okunabilen bir sistem oluşturmaktadır. Yollar, dilimler şeklinde parçalar oluşturmakta olup bunlar fonksiyonların yerleştiği alanlardır. Yolların oluşturduğu çizgisel hatlar fonksiyonların yerleştiği alanların belirginleşmesini, tanımlanmasını ve fonksiyonların bir birinden ayrışmasını sağlayan fiziksel ve algısal hatlar oluşturmaktadır.

\section{Yakınlık}

Tasarım veya mekân dokusu içerisinde mekânsal veya anlamsal olarak bir birine yakın olan unsurlar birlikte ve küme olarak algılanırlar. Bu durum mekân içerisindeki öğelerin sınıflandırılarak algılanmasını kolaylaştırır. Böylece tasarımsal öğe veya fonksiyonlar grup olarak değerlendirilir.

Projede yapısal elemanlar mekânsal ve işlevsel yakınlıkları ile kategorize olmuşlardır. Buna göre, yerleşimdeki konutlar yollar arasına bir düzen şekilde sıralanıp, bir arada değerlendirilerek bir yerleşim kümesi oluşturulmuştur. Bunun dışında, meydanın çevresine sıralanmış bulunan kurum ve ticarethaneler de mekânsal ve fonksiyonel yakınlık ilişkisi içerisinde bir başka küme oluşturmuştur.

\section{Tamamlama}

Tasarım unsurlarının bir düzen oluşturacak şekilde kullanılması yolu ile tasarımdaki eksik parçaların beyin tarafından tamamlanması ve tam bir şekil olarak algılanması durumunu izah eder. Böylesi durumlarda tasarımda değerlendirilen unsurun net ve tam bir şekli ifade etmesi gerekmez. Beyin, unsurdaki eksik parçaları kendisi tamamlar. Bu, tasarımın okunmasını, anlaşıımasını ve algılanmasını kolaylaştırır.

Söz konusu projede yapı düzeni ve yollar bu ilke ile uyumluluk göstermektedir. Yapı kitleleri dairesel yollara paralel olarak yerleştirilmiştir. Ancak tam bir daire düzeni oluşturmaz veya bitişik nizamda dizilim göstermezler. Buna rağmen dizilim ve tekrarla mevcut yapı kitlelerinin kendilerine ayrılmış bölüm dâhilinde bir daire 
oluşturdukları algısı oluşur. Bu etki yerleşim içerisindeki sakinler için de aynı algıyı oluşturacaktır.

\section{Benzerlik}

Bu ilkeye göre; şekilsel açıdan bir birine benzeyen formlar aralarındaki yakınlık durumuna bakılmaksızın beraber algılanır ve birlikte kümelenirler. Benzer şekillerin gruplandırılması ile mekânda tanımlanması gerekli unsur azalacak ve algısal açıdan sadeleşeceğinden mekânın okunması da kolaylaşacaktır. Böylece kullanıcıların rahat ve huzur duyacağı mekânlar ortaya çıkartııı̧mış olur.

Köy projesi tasarımındaki yollar, konutlar ve bunların birlikteliğinden doğan tasarım guruplarının benzerliği yerleşim modelinin farklı yerlerindeyken bile aynı tasarım tecrübeleri, tasarım hafızası ve algılara sahip olunması sonucunu doğuracaktır. Bu benzerlik yapısal öğe ve objeler açısından bir benzerlik olmakla birlikte, asıl etkili ve önemli olan mekânsal benzerliktir. Bu da mekânın tanınmasını ve algılanmasını kolaylaştırır.

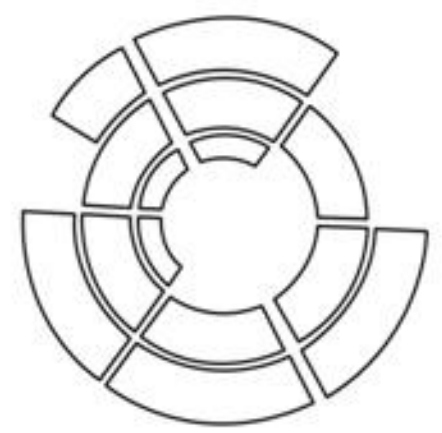

Şekil, zemin

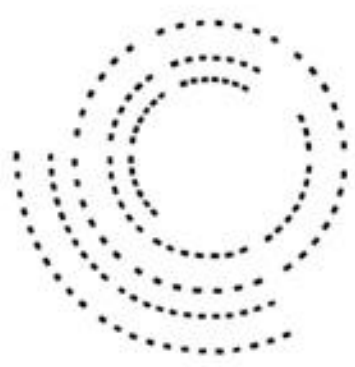

Tamamlama

\section{Süreklilik}

Gestalt'a göre; bir sistem dâhilinde, bir doğrultuda bir birini takip eden tasarım elemanları bir süreklilik oluştururlar. Bu süreklilik hem bir doğrultu ve yön hem de hareketlilik ifadesi olarak algılanır. Bu yöntemle mekan içerisinde algıyı istenilen unsura odaklama, mekan içerisinde yönlendirme ve sirkülasyon sağlamak mümkün kılınır. Ayrıca mekân durağanlıktan çıkartılarak hareket algısı oluşturulur.

Proje çalışmasında içten dışa doğru açılan dairesel yollar bir sürekliliği oluşturmaktadır. Aynı zamanda bu yolları kesen ışınsal yolların kesişimi ve bir düzen halinde ayrılan lateral yol bağlantıları (düğüm noktaları) da süreklilik sağlayarak mekan içerisinde hareketlilik ve sirkülasyon oluşturmaktadır. Yollar üzerine belirli aralık ve sistem dâhilinde sıralanan konutlar da süreklilik etkisi oluşturan diğer yerleşimdeki diğer bir ana unsurdur. Projeden, ışınsal yolların kenarlarına dikildiği anlaşılan ağaçlar da bu sürekliliği artıran bir tasarım unsurudur (Şekil 3).

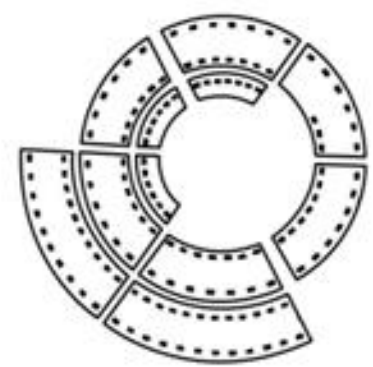

Yakınlık

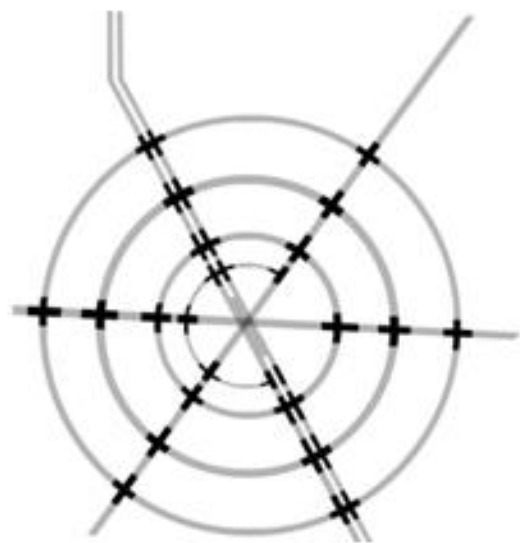

Süreklilik

Şekil 3. Gestalt tasarım öğelerine göre İdeal Cumhuriyet Köyü Projesinin parçaları 


\section{SONUÇ}

Projenin, Atatürk gibi çok yönlü, ileri görüşlü, donanımlı, prensipli ve tüm ihtimalleri değerlendiren bir önderin özellikle üzerinde durup, geliştirilmesine katkı sağlamış olması son derece önemlidir. Proje zamanına göre ileride, geleceğe dönük, ihtiyaç ve beklentileri karşılayacak donanımda hazırlanmıştır. Tasarımı itibariyle, doğada da en çok rastlanan ve doğa ile en uyumlu şekil olan daire ve ışınsal planı temel alması uygulanabilirliğini artırmaktadır. İçeriye doğru merkezi, yakın ilişkili; dışarıya doğru geniş görüş açılı ve manzara hâkim yerleşim şekli modeli cazip kılan etkenlerdendir.

Mekân ve tasarım açısından incelen proje üç farklı kurama göre değerlendirilmiştir. Kuram ilkeleri açısından uygunluğuna bakılan proje, parçalarına ayrılarak çizimlerle betimlenmiştir. Projenin, üç kurama ait ilkeleri çeşitli şekillerde yansıttığı ve karşıladığı görülmüştür. Bu durum, yerleşimin geleneksel köy yerleşimine uygunluğu tartışılabilecekken, mekânsal anlamda uygun bir yerleşim tarzı oluşturduğunu ortaya koymaktadır.

Lynch, Norberg-Shulz ve Gestalt kuramları değerlendirme kriterleri açısından incelendiğinde projede fonksiyonlar arası ilişkiler doğru kurgulanmıştır. Kullanılan ışınsal yollar odaklanmayı ve yönlendirmeyi sağlarken, dairesel yollar mekân algısını ve mekânsal derinliği artırmaktadır. Dairesel dizilimli yapı kitleleri, duvar ve çitler, yollar ve bitkisel materyal algısal ve fiziksel sınırlar teşkil ederek fonksiyon alanlarını güçlendirmektedir. Projede farklı fonksiyonlara sahip pek çok alan oluşturulmuş olup, alanlar arası ilişkiler sistemli bir şekilde tesis edilmiş, içerik ve hizmet amacıyla uyumlu alanlar doğru şekilde kurgulanmıştır. Projede yer alan meydan ve kesişen yolların oluşturduğu düğüm noktaları alana hem hareket kazandırmakta, hem de algıyı ve dikkati aktif tutan sistemli tekrarlar oluşturmaktadır. Ayrıca oluşturulmuş olan düğüm noktaları sirkülasyona da yönlendirmede destek sağlamaktadır. Projede işaret öğesi olarak heykel, değirmen gibi farklı öğelere de yer verilmiştir. Bu öğeler yardımıyla yerleşimin algılanabilirliği ile fark edilebilirliği artırımıştır. Daire formundaki yerleşim ve ışınsal dağılan yapısal sistem bir birini tamamlayarak şekilsel açıdan ilişkili mekânlar oluşturmaktadır. Yakınlık ilişkisi kullanılarak kümelenmiş yapı kitleleri fiziksel ve anlamsal yakınlıkları ile yerleşimi güçlendirmektedir. Kümelenmiş öğeler ve farklı alanlardaki benzer sistemler algısal hafızaya hitap etmektedir. Projede dairesel yollar, bir sistemle sıralanmış yapı kitleleri, plantasyon gibi öğeler süreklilik sağlayan tasarım unsurları olarak sistemi güçlü, hareketli, odaklanılabilir kılmaktadır.

Genel kabulle paralel olarak; yoğun kullanıma sahip ticari, sosyal, kurumsal ve kamusal mekânlar merkezde meydan ve çevresinde yer almaktadır. Daha sakin olması gereken konut alanı yerleşimin daha dış tabakasında konumlandırıımıştır. Köydeki üretim ve işleme faaliyetleri ile ilgili fonksiyonel alanlar ise köy yerleşiminin en dış tabakasında veya yerleşimin belirli mesafelerde uzağında planlanmıştır. Her tabaka bir birinden yeşil kuşaklar ile ayrılmış olup, yerleşimde hem yerleşimde yeşil doku artırılmıs hem de tabakalar arasındaki olumsuz etkileşim en aza indirgenmiştir.

Köy projesi ile ilgili en kritik nokta yerleşim düzeni ve tarzının geleneksel yerleşim dokusuna ne derecede uygun olduğudur. Yapıların mimari dokusu, kullanılan materyal ve tasarım özellikleri açısından özelde geleneksel dokuyu sağlamak mümkündür. Ancak projede bu detaylar yer almadığından proje odaklı olarak değerlendirme yapmak mümkün değildir. Fakat projede yer alan taş, tuğla ve kiremit ocakları gibi yerel yapı malzemelerinin çıkartılması ve üretimine ilişkin tesisler yerleşimin mimari ve tasarımsal dokusunun geleneksel tarzda ve yerel yap materyalleri ile yapılmasının planlandığı izlenimini doğurmaktadır.

Bir köyde sahip olunması gereken fonksiyonları barındırıyor olması, köyün kendi içinde üretim, işleme ve pazarlamasını gerçekleştirebilmesi, eğitim ve kültürel açıdan güçlü olmasını, sosyal açıdan yaşanabilir bir yerleşim olmasını sağlamaktadır. Farklı yörelerdeki farklı zirai faaliyetlere sahip köyler için uyarlama gerektirmektedir. Ancak proje kurgusu gereği bu uyarlamalara imkân tanıyan bir yapıya sahiptir. Bununla birlikte coğrafik, topoğrafik ve iklimsel şartlara göre de uyarlanmayı gerektirmektedir. Kabul edilebilirliği için proje mimari ve tasarımsal özellikler bakımından da kurulduğu bölgenin yerel özellikleri, kültürel yapısı ve geleneklerine göre uyarlanma zorunluluğundadır. 
Özellikle çevresinde barındırdığı rezerv alanlar ile proje aynı zamanda geliştirilmeye de açık bir niteliğe sahiptir.

Proje, hayata geçirilebilmek için önemli bir ekonomik kaynak gerektirmekle birlikte, köydeki üretim, işleme ve pazarlama avantajlarılya kendini uzun dönemde amorti edebilecek alt yapıya sahiptir. Bununla birlikte, barındırdığı özelliklerle ekoturizmi de desteklemekte ve imkânlar doğurmaktadır.

Uyarlama gereklilikleri, kabul edilme, kurulum giderleri gibi bazı sorunlarına karşılık, tüm olumlu özellikleri dikkate alındığında köyden kente göçün önüne geçecek ve köyden göç etmiş olanlarında geriye dönmesini sağlayabilecek nitelikte önemli bir girişim ve alt yapı projesidir. Projenin temel bir model olarak ele alınıp, günümüz şartları, teknolojisi, imkânları ve ihtiyaçlarına göre uyarlanması ve geliştirilmesi olumlu yaklaşımları artıracak; yaşanabilirlik, milli üretime destek, kaynakların doğru kullanımı, kırsal niteliğin korunması, ziraatla geçimi sağlayan kesimin ekonomik yapılarının geliştirilmesini sağlayarak ülkesel kalkınmaya da önemli katkılar sağlayacaktır.

\section{KAYNAKLAR}

Çolakoğlu E (2007) Kırsal Kalkınma Problemine Bir Çözüm Arayışı Olarak Köy- Kent Projesi. ZKÜ Sosyal Bilimler Dergisi, Cilt 3, Sayı 6, ss. 187-202.

Dicle E (2012) Modern Ulus devlet Projesinde Bir İdeal Mekân Temsili Olarak Köy Ütopyası. Turkish Studies, Volume 7/1, p.859-871.

Doğanay F (1993) Kırsal Kalkınma, DPT, Ankara.

Güreşçi E (2010) Türkiye'de Kentten - Köye Göç Olgusu. Doğuş Üniversitesi Dergisi, 11 (1), 77-86.

İnan A (1978) Cumhuriyetin 50. Yılı İçin Köylerimiz. Türk Tarih Kurumu Yayınları, Ankara.

İnan A (1972) Devletçilik Illkesi ve Türkiye Cumhuriyetinin Birinci Sanayi Planı 1933. Türk Tarih Kurumu Yayınları, Ankara.

Ince E (2012) Cumhuriyetin illk Yıllarında Türkiye'de Karayolu Ulaşımına Genel Bir Bakış ve Köyde Ulaşım. ÇTTAD, XII/24, s.s.171-188.

Kapluhan E (2012) Atatürk Dönemi Eğitim Seferberliği Ve Köy Enstitüleri. Marmara coğrafya dergisi sayı: 26, s. 172-194.

Kaypak Ş (2014) Atatürk'ün Kent ve Kentleşmeye Bakışı; Örnek Olay: Ankara'nın Kentleşmesi. Mustafa Kemal Üniversitesi Sosyal Bilimler Enstitüsü Dergisi, Cilt/Volume: 13, Sayı/Issue: 27, s. 349365.

Mevzuat (2016) Köy Kanunu, http://www.mevzuat.gov.tr/MevzuatMetin/1.3.442.pdf, 29.02.2016.

URL (2016) https://tr.wikipedia.org/wiki/K\%C3\%B6y_Enstit\%C3\%BCleri, 28.12.2016.

Sarı M (2014) 442 Sayılı Köy Kanunu Çerçevesinde Cumhuriyet Dönemi Köye Yönelik Çalışmalar. Tarih Okulu Dergisi (TOD), Yıl 7, Sayı XIX, ss. 509-534.

Özen A (2006) Mimari sanal gerçeklik ortamlarında algı psikolojisi, Akademik Bilişim'06 ve Bilgi Teknolojileri Kongresi, Pamukkale Üniversitesi, Denizli, Türkiye, 9-11 Şubat. 